\title{
XRD pattern
}

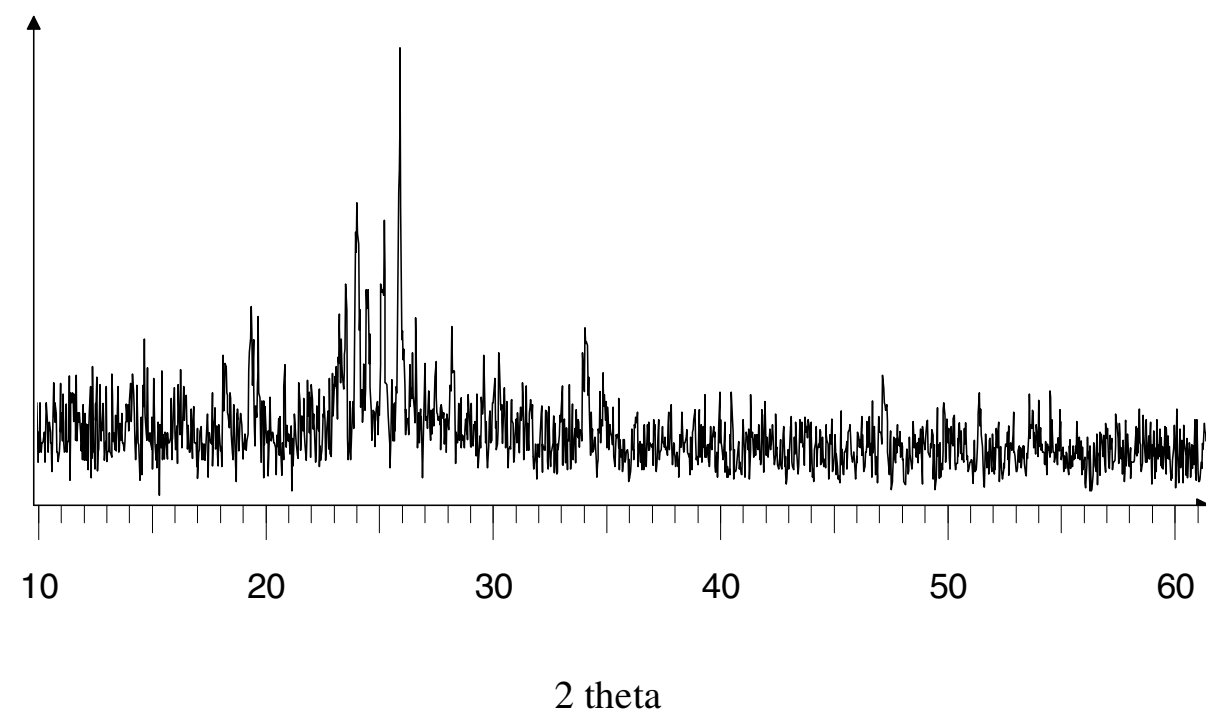

TGA curve

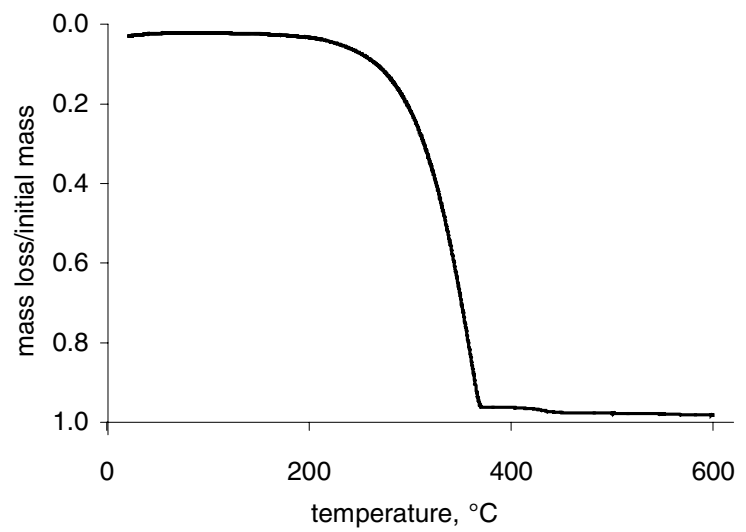

